\title{
Bile Acid Receptor
}

National Cancer Institute

\section{Source}

National Cancer Institute. Bile Acid Receptor. NCI Thesaurus. Code C114912.

Bile acid receptor (486 aa, $56 \mathrm{kDa}$ ) is encoded by the human NR1H4 gene. This protein is involved in both ligand-mediated gene expression and the metabolism of bile acids. 